\title{
MRI findings of rapidly progressive ophthalmoplegia and blindness in mucormycosis
}

\author{
William T. Hu, MD, PhD; Jacqueline A. Leavitt, MD; \\ Eric J. Moore, MD; and John H. Noseworthy, MD
}

A n 18-year-old woman with poorly controlled insulindependent diabetes mellitus had 3 days of worsening nasal discharge, right facial pain and erythema, and headache. Lumbar puncture showed 250 nucleated cells/ $\mu \mathrm{L}$ with neutrophil predominance, elevated protein of $81 \mathrm{mg} / \mathrm{dL}$, and normal glucose. She was treated for presumed meningitis, but then rapidly developed right-side symptoms including facial numbness, complete ophthalmoplegia, and efferent pupillary defect, followed by afferent pupillary defect and acute blindness. Funduscopic examination results were unremarkable, suggesting ischemia as a consequence of presumed vascular thrombosis.

From the Departments of Neurology (W.T.H., J.A.L., J.H.N.), Ophthalmology (J.A.L.), and Otorhinolaryngology (E.J.M.), Mayo Clinic College of Medicine, Rochester, MN.

Disclosure: The authors report no conflicts of interest.

Address correspondence and reprint requests to Dr. William T. Hu, Department of Neurology, Mayo Clinic College of Medicine, 200 First Street, SW, Rochester, MN 55905; e-mail: hu.william@mayo.edu
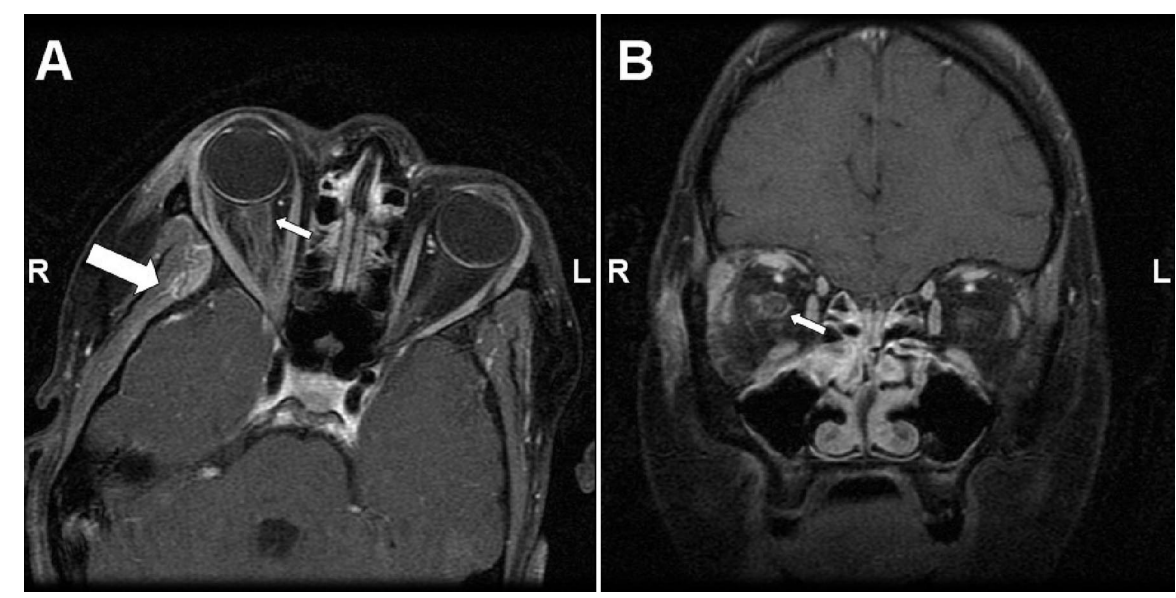

Figure. T1-weighted MR images of the orbits with gadolinium in axial (A) and coronal (B) views. There was abnormal enhancement in the right $(R)$ orbit encasing the optic nerve (small arrow), the periorbital fat, and the right infratemporal musculature (large arrow). There was no imaging abnormality on the left $(L)$.

Imaging was performed (figure). Emergent surgical debridement showed extensive necrosis and mucormycosis. Pathologic studies showed fungal hyphae in the branches of the ophthalmic artery and in the optic nerve perineural sheath without significant optic nerve inflammation. Bacterial orbital cellulitis often spares vision. Rhinocerebral mucormyco- sis should be suspected in the setting of rapidly progressive ophthalmoplegia and blindness in patients with diabetes. ${ }^{1}$

\section{Reference}

1. Brown RB, Lau SK. Case records of the Massachusetts General Hospital. Weekly clinicopathological exercises. Case 3-2001: a 59year-old diabetic man with unilateral visual loss and oculomotor-nerve palsy. N Engl J Med 2001;344:286-293. 


\section{Neurology}

\section{MRI findings of rapidly progressive ophthalmoplegia and blindness in mucormycosis}

William T. Hu, Jacqueline A. Leavitt, Eric J. Moore, et al.

Neurology 2006;66; E40

DOI 10.1212/01.wnl.0000204231.85308.7e

This information is current as of May 22, 2006

\section{Updated Information \& Services}

References

Subspecialty Collections

Permissions \& Licensing

Reprints including high resolution figures, can be found at: http://n.neurology.org/content/66/10/E40.full

This article cites 1 articles, 0 of which you can access for free at: http://n.neurology.org/content/66/10/E40.full\#ref-list-1

This article, along with others on similar topics, appears in the following collection(s):

All Neuro-ophthalmology

http://n.neurology.org/cgi/collection/all_neuroophthalmology Fungal infections

http://n.neurology.org/cgi/collection/fungal_infections MRI

http://n.neurology.org/cgi/collection/mri

Ocular motility

http://n.neurology.org/cgi/collection/ocular_motility

Optic nerve

http://n.neurology.org/cgi/collection/optic_nerve

Information about reproducing this article in parts (figures,tables) or in its entirety can be found online at:

http://www.neurology.org/about/about_the_journal\#permissions

Information about ordering reprints can be found online:

http://n.neurology.org/subscribers/advertise

Neurology ${ }^{\circledR}$ is the official journal of the American Academy of Neurology. Published continuously since 1951, it is now a weekly with 48 issues per year. Copyright . All rights reserved. Print ISSN: 0028-3878. Online ISSN: 1526-632X.

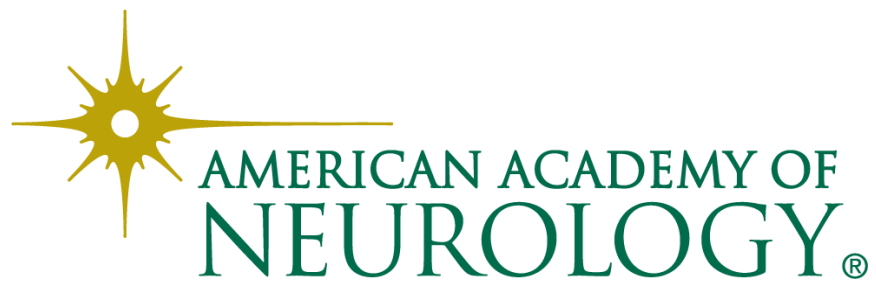

